\title{
Peranan Kinerja Penyuluh Pertanian Terhadap Peningkatan Produktivitas Padi Sawah di Kabupaten Labuhanbatu Utara
}

\section{The Role of Agricultural Extension Worker Performance in Increasing Rice Paddy Productivity in North Labuhanbatu District}

\author{
Fachruddin Nasution'), Yusniar Lubis's), Syaifuddin ${ }^{3)}$ \\ 1) Magister Agribisnis, Pascasarjana, Universitas Medan Area, Indonesia \\ 2) Magister Agribisnis, Pascasarjana, Universitas Medan Area, Indonesia \\ 3) Fakultas Ekonomi, Universitas Prima Indonesia, Indonesia
}

\begin{abstract}
Abstrak
Penelitian ini bertujuan untuk mengetahui kinerja penyuluh pertanian dan untuk menganalisis perbedaan produktivitas padi sawah di daerah antara kinerja penyuluh tinggi dengan kinerja penyuluh rendah di Kabupaten Labuhanbatu Utara. Penelitian menggunakan metode survey dan dilaksanakan di Kabupaten Labuhanbatu Utara selama 3 (tiga) bulan, mulai bulan April 2016 s.d. bulan Juni 2016. Jumlah sampel penelitian sebanyak 100 petani padi sawah yang dibagi 2 kelompok yaitu untuk desa-desa dengan kinerja tinggi sebanyak 45 petani sampel sedangkan jumlah sampel untuk desa-desa dengan kinerja rendah sebanyak 55 orang. Data penelitian dianalisis secara statistik menggunakan analisis uji beda rata-rata (T test analysis) menggunakan software SPPS versi 19. Hasil penelitian tersebut diperoleh $t_{\text {cari }}=9,006$ sedangkan tingkat signifikansi yaitu 0,000 lebih kecil dari 0,01 dengan demikian dapat disimpulkan terima Ha dan tolak Ho. Artinya ada perbedaan yang sangat signifikan antara produktivitas padi sawah daerah kinerja penyuluh tinggi dengan daerah kinerja penyuluh rendah pada tingkat kepercayaan $99 \%$ di daerah penelitian.

Kata kunci: Padi Sawah, Penyuluh, Kinerja, Produktivitas, Perbedaan
\end{abstract}

\begin{abstract}
Fachruddin Nasution, conducted a study entitled: "The Role of Agricultural Extension Performance with Rice Productivity Improvement in North Labuhan Batu Regency". This study aims to determine the performance of agricultural extension and to analyze the differences in the productivity of paddy in the area between the highperformance extension educator with low performance in North Labuhan Batu Regency. The study used survey methods and implemented in North Labuhan Batu Regency for 3 (three) months, starting in April 2016 s.d. In June, 2016. Total sample of 100 farmers of paddy were divided into 2 groups, for villages with high performance as much as 45 farmers sample while the sample size for the villages with low performance as many as 55 people. The research data were statistically analyzed using analysis of different test average (T test analysis) using SPSS software version19. The results obtained $t=9.006$ while find a significance level that is 0,000 less than 0.01 can thus be concluded accept and reject Ho Ha. This means that there are significant differences between the productivity of lowland rice areas of high performance with the performance area extension educator lower at 99\% confidence level in the study area.
\end{abstract}

Keywords: Rice, Extension, Performance, Productivity, Difference

How to Cite: Nasution, Fachrudin, Y. Lubis \& Syaifuddin. (2020). Peranan Kinerja Penyuluh Pertanian Terhadap Peningkatan Produktivitas Padi Sawah di Kabupaten Labuhanbatu Utara. Jurnal Ilmiah Magister Agribisnis, 2(2) 2020: 12-23,

*E-mail: Yusniar@uma.ac.id ISSN 2550-1305 (Online) 

Fachruddin Nasution, Yusniar Lubis \& Syaifuddin, Peranan Kinerja Penyuluh Pertanian Terhadap Peningkatan Produktivitas Padi Sawah di Kabupaten Labuhanbatu Utara.

\section{PENDAHULUAN}

Indonesia adalah negara agraris dimana sebagian besar penduduknya hidup dari hasil bercocok tanam atau bertani, sehingga pertanian merupakan sektor yang memegang peranan penting dalam kesejahteraan kehidupan penduduk Indonesia. Peranan sektor pertanian memiliki kontribusi bagi pembentukan Produk Domestik Bruto (PDB) sebesar 15,3\% pada tahun 2009 berdasarkan harga berlaku. Jika dilihat dari nilai absolutnya, maka kontribusi sektor pertanian terhadap PDB merupakan jumlah yang besar, sehingga seharusnya dapat dianalogikan bahwa petani seharusnya menerima pendapatan yang memadai untuk dapat hidup sejahtera. Namun pada kenyataannya, apabila dilihat melalui peta kemiskinan di Indonesia, kiranya dapat dipastikan bahwa bagian terbesar penduduk yang miskin adalah yang bekerja di sektor pertanian (Tambunan, 2003 : 23-24). Hal ini menyebabkan bidang pertanian harus dapat memacu diri untuk dapat meningkatkan produk pertaniannya, khususnya produk pertanian tanaman pangan. Salah satu komoditi tanaman pangan potensial untuk dikembangkan adalah tanaman padi.

Sektor pertanian berperan penting dalam menyediakan bahan pangan bagi seluruh penduduk maupun menyediakan bahan baku bagi industri, dan untuk perdagangan ekspor (Suparta, 2010). Hal ini diawali dengan meningkatkan kualitas sumberdaya manusia yang baik, dimana setiap individu dalam rumah tangga mendapatkan asupan pangan dalam jumlah yang cukup, aman, dan bergizi secara berkelanjutan yang pada gilirannya akan meningkatkan status kesehatan dan memberikan kesempatan agar setiap individu mencapai potensi maksimumnya. Dengan demikian ketahanan pangan merupakan komponen yang tak terpisahkan dari ketahanan nasional, dimana ketahanan nasional berkaitan erat dengan kualitas sumber daya manusia.

Isu ketahanan pangan menjadi topik penting karena pangan merupakan kebutuhan paling hakiki yang menentukan kualitas sumber daya manusia dan stabilitas sosial politik sebagai prasyarat untuk melaksanakan pembangunan (Ilham, dkk, 2006). Ketahanan pangan ini menjadi semakin penting karena pangan bukan hanya merupakan kebutuhan dasar (basic need) tetapi juga merupakan hak dasar (basic right) bagi setiap umat manusia yang wajib dipenuhi. Oleh karena pangan merupakan hak dasar itulah, maka negara berkewajiban untuk memastikan bahwa setiap individu warga negara telah mendapatkan haknya atas pangan (Hariyadi, dkk, 2009). Program peningkatan ketahanan pangan diarahkan untuk dapat memenuhi kebutuhan pangan masyarakat di dalam negeri dari produksi pangan nasional. Ketahanan pangan bagi suatu negara merupakan hal yang sangat penting, terutama bagi negara yang mempunyai jumlah penduduk sangat banyak seperti Indonesia. Jumlah penduduk Indonesia diperkirakan mencapai 220 juta jiwa pada tahun 2020 dan diproyeksikan 270 juta jiwa pada tahun 2025 (Hanafie, $2010: 272$ ).

Sebagian besar petani padi merupakan masyarakat miskin atau berpendapatan rendah, rata-rata pendapatan rumah tangga petani masih rendah, yakni hanya sekitar $30 \%$ dari total pendapatan keluarga (Mardianto, 2001). Selain berhadapan dengan rendahnya pendapatan yang diterima petani, sektor pertanian juga dihadapkan pada penurunan produksi dan produktivitas hasil pertanian. Untuk memecahkan masalah tersebut, pemerintah melancarkan dua pendekatan pembangunan pertanian. Pertama pembangunan pertanian berwawasan agribisnis dan kedua, pembangunan pertanian tidak lagi dipandang sebagai pembangunan parsial pengembangan komoditas tetapi di dalam implementasinya sangat terkait dengan pembangunan wilayah. 
Kabupaten Labuhanbatu Utara merupakan salah satu lumbung padi di Provinsi Sumatera Utara dengan produksi mencapai $130.705,70$ ton pada tahun 2014, yang dihasilkan dari 24.902,00 Ha sawah. Petugas yang berhubungan langsung dengan petani padi sawah adalah penyuluh pertanian. Dalam pelaksanaan tugas penyuluh pertanian memiliki peran sebagai penasehat, teknisi, penghubung, organisatoris dan agen pembaharu yang langsung membina petani di lahan usahataninya.

Dalam pelaksanaan tugas, penyuluh pertanian di Labuhanbatu Utara dihadapkan pada masalah yaitu persepsi yang berbeda pada tingkat petani tentang inovasi baru yang dibawa oleh penyuluh pertanian. Dalam proses penyuluhan pertanian, diharapkan terjadi penerimaan sesuatu yang baru oleh petani yang disebut adopsi. Penerimaan di sini mengandung arti tidak sekedar tahu, tetapi sampai benar-benar dapat melaksanakan atau menerapkan dengan benar serta menghayatinya dalam usahatani padi sawah. Adopsi teknologi oleh petani dilakukan melalui tahap: mengetahui, memperhatikan, menilai, mencoba dan menerapkan. Jika teknologi produksi padi yang diajarkan penyuluh dapat diterapkan oleh petani maka akan terjadi peningkatan produktivitas padi sawah.

Pelaksanaan tugas penyuluh bila diukur dari sisi kinerja maka akan terdapat kinerja penyuluh yang tinggi dan kinerja penyuluh yang rendah. Seberapa besar kinerja penyuluh pertanian mempengaruhi produktivitas padi sawah tentu harus dapat dianalisis secara statistik, sehingga hasilnya dapat menjadi pertimbangan dalam mengambil keputusan bagi program kerja penyuluh pertanian dimasa yang akan datang. Berdasarkan uraian pada latar belakang maka penulis tertarik untuk melakukan penelitian tentang "Peranan Kinerja Penyuluh Pertanian terhadap Peningkatan Produktivitas Padi Sawah di Kabupaten Labuhanbatu Utara". Penelitian ini diharapkan dapat membuktikan bahwa terdapat perbedaan antara produktivitas padi sawah di daerah dengan kinerja penyuluh tinggi dan daerah dengan kinerja penyuluh rendah di Kabupaten Labuhanbatu Utara.

\section{METODE PENELITIAN}

Pemilihan lokasi penelitian dilakukan secara sengaja (purposive). Penelitian dilaksanakan selama 3 (tiga) bulan, mulai bulan April 2016 s.d. bulan Juni 2016. Kabupaten Labuhanbatu Utara terdiri dari 8 kecamatan. Pemilihan kecamatan sampel dilakukan secara sengaja yaitu Kecamatan Kualu Hulu, Kualuh Selatan, Kuala Ledong dan Populasi Kualuh Hilir dengang pertimbang di empat kecamatan tersebut terdapat desadesa dengan penilaian kinerja penyuluh yang baik dan kinerja penyuluh yang rendah. Populasi dalam penelitian ini terdiri dari 2 (dua) kelompok yaitu: 1) Petani padi sawah yang berada pada desa-desa dengan dengan kinerja penyuluh yang tinggi, 2) Petani padi sawah yang berada pada desa-desa dengan dengan kinerja penyuluh yang rendah.

Populasi petani padi sawah di Kabupaten Labuhanbatu Utara sebanyak 16.052 orang petani. Metode penentuan sampel untuk petani padi sawah menggunakan metode Simple Random Sampling (sampel acak sederhana) yaitu proses pengambilan sampel yang dilakukan dengan memberi kesempatan yang sama pada setiap anggota populasi untuk menjadi anggota sampel. Anggota dari populasi dipilih satu persatu secara random (semua populasi mendapatkan kesempatan yang sama untuk dipilih) dan jika sudah dipilih maka tidak dapat dipilih lagi responden yang dipilih memiliki kriteria yaitu petani yang lokasi usahataninya berada di kecamatan yang telah ditentukan.

Ukuran sampel yang diambil harus dihitung terlebih dahulu agar sampel yang diambil dapat mewakili populasi salah satu rumus yang dapat digunakan untuk 
menentukan jumlah sampel minimal jika diketahui ukuran populasi adalah rumus Slovin (Umar 2003), dengan rumus sebagai berikut:

$$
n=\frac{N}{1+N e^{2}}
$$

Keterangan :

$\mathrm{N}=$ Jumlah populasi

$\mathrm{n}=$ Jumlah sampel

$\mathrm{e}=$ kesalahan pengambilan sampel ditetapkan sebesar $10 \%$

Dengan menggunakan rumus Slovin di atas maka diperoleh petani sampel sebagai berikut.

$\mathrm{n}=16.052 /\left[1+16.052(0,1)^{2}\right]$

$\mathrm{n}=99,4$ digenapkan menjadi 100 orang

Sampel penelitian sebanyak 100 petani padi sawah dibagi menjadi 2 (dua) bagian yaitu petani sampel untuk daerah dengan kinerja penyuluh tinggi dan petani sampel untuk daerah dengan kinerja penyuluh rendah. Kecamatan sampel ditentukan dengan sengaja, dengan pertimbangan dikecamatan tersebut terdapat desa dengan kinerja penyuluh tinggi dan rendah. Jumlah petani sampel tersebut selanjutnya diambil secara proposional (proportional random sampling) untuk menentukan jumlah sampel masingmasing desa. Populasi dan petani sampel di daerah penelitian disajikan pada Tabel 1 berikut.

Tabel 1 menunjukkan bahwa secara proposional diperoleh sampel penelitian untuk masing-masing desa perkecamatan. Jumlah sampel untuk desa-desa dengan kinerja tinggi sebanyak 45 petani sampel sedangkan jumlah sampel untuk desa-desa dengan kinerja rendah sebanyak 55 orang.

Data yang digunakan adalah data primer dan data sekunder. Masalah 1 dianalisis dengan menggunakan analisis deskriptif. Analisis deskriptif untuk menggali tentang kinerja penyuluh pertanian lapangan (PPL) yang diukur dengan skala likert (skor). Masalah 2 dianalisis secara statistik menggunakan analisis uji beda rata-rata ( $T$ test analysis) menggunakan software SPPS versi 19. Uji beda rata-rata untuk menguji tingkat perbedaan antara produktivitas padi sawah di daerah dengan kinerja penyuluh tinggi dan daerah dengan kinerja penyuluh rendah di Kabupaten Labuhanbatu Utara. Formulasinya matematis sebagai berikut : (Sugiono, 2010)

Dimana:

$\overline{\mathrm{X}}_{1}$ dan $\overline{\mathrm{X}}_{2}=$ Rata-rata produktivitas padi sawah di daerah dengan kinerja penyuluh tinggi dan daerah dengan kinerja penyuluh rendah.

$\mathrm{S}_{1}{ }^{2}$ dan $\mathrm{S}_{2}{ }^{2}=$ Rata-rata varian produktivitas padi sawah di daerah dengan kinerja penyuluh tinggi dan daerah dengan kinerja penyuluh rendah.

$\mathrm{n}_{1}$ dan $\mathrm{n}_{2}=$ Jumlah sampel petani produktivitas padi sawah di daerah dengan kinerja penyuluh tinggi dan daerah dengan kinerja penyuluh rendah.

Pengujian hipotesis sebagai berikut:

Ha yaitu ada perbedaan signifikan produktivitas padi sawah di daerah dengan kinerja penyuluh tinggi dan daerah dengan kinerja penyuluh rendah 
Ho yaitu tidak ada perbedaan signifikan produktivitas padi sawah di daerah dengan kinerja penyuluh tinggi dan daerah dengan kinerja penyuluh rendah.

Kriteria Uji :

Terima Ha dan tolak Ho apabila t-hitung $>$ t-tabel, db =n-1, $\alpha=0.05$

Tolak Ha dan terima Ho apabila t-hitung $<$ t-tabel, $\mathrm{db}=\mathrm{n}-1, \alpha=0.05$

Penggunaan alpha sebesar 5\% dalam uji statistik t-hitung sesuai dengan kebutuhan peneliti yang juga didasarkan pada pernyataan Usman, dkk (2008:85), bahwa dalam penelitian sosial, besarnya alpha (tingkat kesalahan) yang digunakan dapat bernilai $1 \%$ atau $5 \%$ atau tingkat keyakinan $95 \%$ dan $99 \%$.

\section{HASIL DAN PEMBAHASAN}

Penilaian Kinerja Penyuluh Pertanian Lapangan

Hasil penelitian mengenai kinerja penyuluh pertanian lapangan (PPL) di daerah penelitian dengan 9 (sembilan) indikator terdapat PPL yang mempunyai kinerja baik (tinggi) dan kinerja kurang baik (rendah). Penilaian kinerja PPL didasarkan nilai total dari masing-masing jawaban indikator yang diberikan PPL dan dicocokan dengan laporan ruting di Kantor WKPP masing-masing dilapangan. Hasil rekapitulasi penilaian kinerja PPL sesuai dengan kecamatan dan desa sampel dapat dilihat pada tabel berikut:

Tabel 1. Hasil Penilaian Kinerja PPL di Daerah Penelitian

\begin{tabular}{|c|c|c|c|c|}
\hline Kecamatan & Desa & Total Nilai & $\begin{array}{l}\text { Nilai Prestasi } \\
\text { Kerja }\end{array}$ & Prestasi Kerja \\
\hline \multirow[t]{3}{*}{ Kuala Hulu } & Kuala Beringin & 61 & 76.25 & BAIK \\
\hline & Parpaudangan & 66 & 82.5 & BAIK \\
\hline & Pulo Dogom & 48 & 60 & KURANG \\
\hline \multirow[t]{5}{*}{ Kualuh Selatan } & Sidua-dua & 65 & 81.25 & BAIK \\
\hline & Gunung Melayu & 67 & 83.75 & BAIK \\
\hline & Siamporik & 62 & 77.5 & BAIK \\
\hline & Hasang & 48 & 60 & KURANG \\
\hline & Lobu Huala & 48 & 60 & KURANG \\
\hline \multirow[t]{5}{*}{ Kuala Ledong } & Simandulang & 61 & 76.25 & BAIK \\
\hline & Teluk Pule Dalam & 66 & 82.5 & BAIK \\
\hline & Tanjung Ledong & 43 & 53.75 & KURANG \\
\hline & Pangkal Linang & 44 & 55 & KURANG \\
\hline & Teluk Pule Luar & 47 & 58.75 & KURANG \\
\hline \multirow[t]{6}{*}{ Kualuh Hilir } & Sei Apung & 64 & 80 & BAIK \\
\hline & Teluk Pie & 65 & 81.25 & BAIK \\
\hline & Kampung Masjid & 64 & 80 & BAIK \\
\hline & Teluk Binjei & 43 & 53.75 & KURANG \\
\hline & Kuala Bangka & 46 & 57.5 & KURANG \\
\hline & Sei Sentang & 46 & 57.5 & KURANG \\
\hline
\end{tabular}


Fachruddin Nasution, Yusniar Lubis \& Syaifuddin, Peranan Kinerja Penyuluh Pertanian Terhadap Peningkatan Produktivitas Padi Sawah di Kabupaten Labuhanbatu Utara.

Tanjung Mangedar

46

57.5

KURANG

Sumber: Data Primer dan Sekunder (diolah), 2016

Tabel 1 di atas menunjukkan bahwa di Kecamatan Kuala Hulu desa memiliki PPL dengan kinerja tinggi adalah Desa Kuala Beringin dan Parpaudangan, sedangkan dengan dengan kinerja PPL rendah adalah Desa Pulo Dogom. Di Kecamatan Kualuh Selatan desa yang mempunyai kinerja PPL tinggi adalah Desa Sidua-dua, Gunung Melayu dan Siamporik, sedangkan desa dengan kinerja PPL rendah adalah Desa Hasang dan Lobu Huala. Di Kecamatan Kuala Ledong desa yang mempunyai PPL dengan kinerja tinggi adalah Desa Simandulang dan Teluk Pule Dalam, sedangkan desa dengan kinerja PPL rendah adalah Desa Tanjung Ledong, Pangkal Linang dan Teluk Pule Luar. Di Kecamatan Kualuh Hilir desa yang mempunyai PPL dengan kinerja tinggi adalah desa Sei Apung, Teluk Pie dan Kampung Masjid, sedangkan desa dengan kinerja rendah adalah Desa Teluk Binjei, Kuala Bangka, Sei Sentang dan Tanjung Mangedar.

Luas lahan rata-rata yang diusahakan petani sampel yaitu 1,1 hektar merupakan luas yang memadai secara ekonomis untuk usahatani padi sawah. Umur rata-rata petani sampel yaitu 42,51 tahun merupakan umur produktif seorang petani dimana masih memiliki kemampuan dalam hal tenaga dan pemikiran. Tingkat pendidikan rata-rata petani sampel yaitu 8,6 tahun merupakan pendidikan yang rendah sehingga sebagian petani akan sulit dalam menerima teknologi baru di bidang pertanian Semakin tinggi pendidikan seorang petani akan memudahkan petani untuk mempelajari sagala sesuatu yang berkaitan dengan usahataninya. Pengalaman rata-rata petani sampel dalam berusahatani padi sawah yaitu 11,93 tahun merupakan pengalaman yang cukup panjang sehingga petani memiliki pengetahuan dan wawasan yang baik dalam mengelola usahatani padi sawah yang dimilikinya sehingga resiko kegagalan semakin kecil. Semakin lama pengalaman berusahatani seorang petani akan semakin ahli di biadangnya. Jumlah tanggungan keluarga rata-rata petani sampel yaitu 5 orang adalah tanggungan keluarga yang sedang, dimana petani harus bekerja kerja untuk memenuhi kebutuhan keluarganya.

Rata-rata pengunaan tenaga kerja usahatani padi sawah di daerah kinerja penyuluh rendah sebesar 34,6 $\mathrm{HK} / \mathrm{Ha} / \mathrm{MT}$. Pengunaan rata-rata tenaga kerja yang paling besar berada di Desa Pangkal Unang yaitu $38 \mathrm{HK} / \mathrm{Ha}$ /MT sedangkan yang paling kecil berada di Desa Sei Sentang yaitu $33 \mathrm{HK} / \mathrm{Ha} / \mathrm{MT}$. Penggunaan bibit padi rata-rata di daerah penelitian sebesar $21,25 \mathrm{Kg} / \mathrm{Ha} / \mathrm{MT}$. Penggunaan bibit padi tertinggi berada di Desa Lobu Houla sebesar $23,14 \mathrm{Kg} / \mathrm{Ha} / \mathrm{MT}$ sedangkan yang terendah berada di beberapa desa yaitu sebesar $20 \mathrm{Kg} / \mathrm{Ha} / \mathrm{MT}$.

Usahatani padi sawah tidak terlepas dari penggunaan pupuk, pestisida dan ZPT. Ketiga faktor produksi tersebut adalah upaya untuk memperoleh produksi yang baik dari tanaman padi sawah. Adapun penggunaan rata-rata pupuk, pestisida dan ZPT di daerah kinerja penyuluh tinggi dilihat pada tabel berikut. 
Produktivitas padi sawah adalah produksi gabah kering panen yang dihasilkan persatuan luas lahan yang ditanami padi sawah. Produktivitas padi sawah sangat dipengaruhi oleh faktor-faktor produksi yang digunakan oleh petani dan faktor lingkungan yaitu iklim dan kesesuaian tanah bagi tanaman padi sawah. Adapun produktivitas padi sawah di daerah kinerja penyuluh tinggi dan rendah dapat dilihat pada tabel berikut.

Tabel 2 Produktivitas Padi Sawah Di Daerah Kinerja Penyuluh Tinggi dan Rendah

\begin{tabular}{lll}
\hline & \multicolumn{2}{l}{ Produktivitas (Kw/Ha) } \\
\cline { 2 - 3 } No & Kinerja Penyuluh Tinggi & Kinerja Penyuluh Rendah \\
\hline 1 & 53.60 & 49.31 \\
2 & 53.95 & 49.50 \\
3 & 53.98 & 49.43 \\
4 & 54.00 & 49.40 \\
5 & 53.94 & 49.86 \\
6 & 50.47 & 49.95 \\
7 & 50.50 & 49.76 \\
8 & 55.71 & 48.24 \\
9 & 54.98 & 49.95 \\
10 & 55.00 & 50.88 \\
\hline Rata-Rata & 53.83 & 49.72 \\
\hline
\end{tabular}

Sumber: Data Primer Diolah, 2016

Dari tabel 2 di atas menunjukkan untuk daerah dengan kinerja penyuluh tinggi produktivitas padi sawah rata-rata yaitu sebesar 53,83 Kwintal/Hektar/Musim Tanam (Kw/Ha/MT) atau 5,383 Ton/Ha/MT. Sedangkan daerah dengan kinerja penyuluh rendah produktivitas padi sawah rata-rata yaitu sebesar 49,72 $\mathrm{Kw} / \mathrm{Ha} / \mathrm{MT}$ atau 4,972 Ton/Ha/MT. Terdapat selisih produktivitas antara keduanya sebesar 4,11 Kw/Ha/MT atau 0,411 Ton/Ha/MT. Artinya daerah dengan kinerja penyuluh tinggi mempunyai produktivitas padi sawah lebih tinggi sebesar 4,11 Kw/Ha/MT atau 0,411 Ton/Ha/MT. Secara perhitungan ekonomi pertanian angka tersebut tentu sangat besar bila dikonversikan dengan total luas lahan sawah yang ditanami padi sawah di daerah penelitian. Jadi kesimpulan awal menyatakan bahwa benar peningkatan kinerja penyuluh pertanian dapat meningkatkan produktivitas padi sawah di daerah penelitian. Namun untuk mengambil kesimpulan secara statistic perlu dilanjutkan dengan uji statistic untuk melihat apakah terjadi perbedaan yang signifikan produktivitas padi sawah antara daerah kinerja penyuluh tinggi dengan daerah kinerja penyuluh rendah.

Perbedaan Produktivitas Padi Sawah Di Kinerja Penyuluh Tinggi dengan Kinerja Penyuluh Rendah

Berdasarkan hasil pengolahan data produktivitas padi sawah daerah kinerja penyuluh tinggi dan kinerja penyuluh rendah dengan uji $t$-test menggunakan alat analisis statistik SPSS versi18 diperoleh hasil analisis uji t-test untuk melihat perbedaan keduanya diperoleh hasil disajikan pada tabel 3. 
Untuk lebih meyakinkan apakah perbedaan tersebut nyata atau tidak nyata secara statistik, maka dilakukan pengujian statistik uji "t". Batas atas perbedaan produktivitas padi sawah di daerah kinerja penyuluh tinggi dengan daerah kinerja penyuluh rendah 5,32482 $\mathrm{Kw} / \mathrm{Ha} / \mathrm{MT}$ sedangkan batas bawah adalah 3,3774 Kw/Ha/MT. Dari hasil perhitungan tersebut diperoleh $t_{\text {cari }}=9,006$ sedangkan tinggkat signifikansi yaitu 0,000 lebih kecil dari 0,01 dengan demikian dapat disimpulkan terima Ha dan tolak Ho. Artinya ada perbedaan yang sangat signifikan antara produktivitas padi sawah daerah kinerja penyuluh tinggi dengan daerah kinerja penyuluh rendah pada tingkat kepercayaan 99\% di daerah penelitian.

Tabel 3 Hasil Uji Beda Rata-Rata

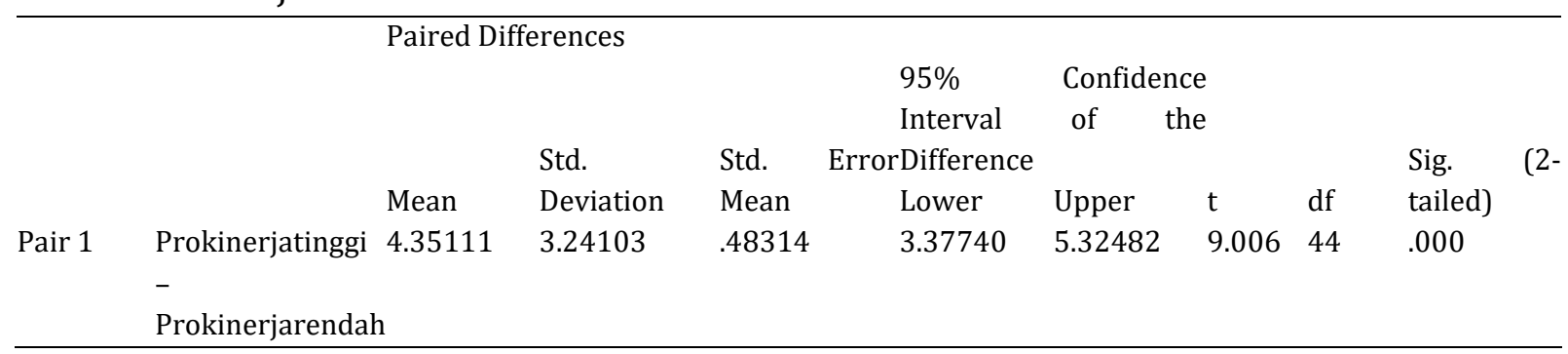

Sumber: Data Primer Diolah, 2016

Petani merupakan subjek utama yang menentukan kinerja produktivitas usahatani yang dikelolanya. Secara naluri petani menginginkan usahataninya memberikan manfaat tertinggi dari sumber daya yang dikelola. Produktivitas sumber daya usahatani sangat tergantung pada teknologi yang diterapkan, sehingga kemampuan dan kemauan petani dalam menggunakan teknologi yang didorong oleh aspek sosial dan ekonomi merupakan syarat mutlak tercapainya usaha pengembangan pertanian dalam rangka meningkatkan produktivitas di suatu daerah.

Penyuluhan pertanian telah memainkan peranan penting dalam peningkatan produksi pertanian di daerah penlitian yaitu Kabupaten Labuhanbatu Utara. Perjalanan pengembangan penyuluhan pertanian sejak dulu mengalami pasang surut dan liku-liku yang dinamik sesuai dengan perkembangan zaman dan berperan penting dalam pembangunan pertanian yang merupakan bagian dari pembangunan daerah serta merupakan proses transformasi dari pertanian tradisional menjadi pertanian tangguh yang mampu memanfaatkan sumber daya secara optimal, mampu melakukan penyesuaian diri dalam pola dan struktur produksinya terhadap perubahan sikap, perilaku, pengetahuan dan keterampilan petani dan keluarganya sebagai hasil dari proses belajar mengajar.

Penyelenggaraan penyuluhan pertanian akan berjalan dengan baik apabila ada persamaan persepsi antara penyuluh dan petani serta pihak-pihak yang berkepentingan. Penyuluhan pertanian yang dilaksanakan secara bersama oleh pemerintah Provinsi dan Kabupaten/Kota, harus jelas memiliki keserasian dan persamaan tujuan antar susunan 
pemerintah tersebut sehingga mampu menyelesaikan seluruh permasalahan yang dihadapi petani selama ini.

Pada dasarnya pengetahuan dan wawasan yang memadai dari kegiatan penyuluhan dinilai dapat digunakan untuk memecahkan sebagian masalah yang dihadapi oleh petani, akan tetapi pada kenyataannya sebagian petani tidak ikut berpartisipasi dalam kegiatan penyuluhan bahkan adanya kecenderungan tidak percaya dengan program yang diadakan oleh penyuluh pertanian hingga saat ini. Dari permasalahan ini maka penerapan teknologi yang selama ini di tawarkan oleh penyuluh menjadi kurang diperhatikan sehingga tingkat penerapan teknologi pertanian dalam mendukung usahataninya juga menjadi semakin rendah.

Penyuluhan pertanian merupakan agen perubahan yang langsung berhubungan dengan petani. Fungsi utamanya yaitu mengubah perilaku petani dengan pendidikan non formal sehingga petani mempunyai kehidupan yang lebih baik secara berkelanjutan. Penyuluh dapat mempengaruhi sasaran dalam perannya sebagai motivator, edukator, dinamisator, organisator, komunikator, maupun sebagai penasehat petani (Jarmie 2000). Menurut Mounder dalam Suriatna (1988:1) menjelaskan bahwa penyuluhan pertanian sebagai sistem pelayanan yang membantu masyarakat melalui proses pendidikan dalam pelaksanaan teknik dan metode berusahatani untuk meningkatkan produksi agar lebih berhasil guna dalam upaya meningkatkan pendapatan.

Dalam proses penyuluhan pertanian diharapkan terjadi penerimaan sesuatu yang baru oleh petani yang disebut adopsi. Penerimaan disini mengandung arti tidak sekedar tahu, tetapi sampai benar-benar dapat melaksanakan atau menerapkan dengan benar serta menghayatinya dalam usahatani padi. Jika teknologi produksi padi yang diajarkan penyuluh dapat diterapkan oleh petani maka akan terjadi peningkatan produksi padi. Kondisi pertanian rakyat masih lemah dalam banyak aspek, sementara tantangan yang dihadapi semakin berat, untuk itu diperlukan kegiatan penyuluhan dan peran penyuluh yang makin intensif, berkesinambungan dan terarah. Peran penyuluhan pertanian harus berada dalam posisi yang strategis dimana dalam penyelenggaraannya terkoordinir dengan baik dan bisa berjalan efektif dan efisien. Petani padi perlu mendapatkan inspirasi yang terbaru agar tumbuh motivasi dan gairah usaha dengan konsistensi dan komitmen yang tinggi dalam upaya peningkatan produksi padi.

Mengacu pada hasil penelitian dimana terdapat perbedaan yang sangat signifikan produktivitas padi sawah antara daerah kinerja penyuluh tinggi dan daerah kinerja penyuluh rendah. Jika ditelusuri lebih dalam penyebab perbedaan tersebut adalah bermuara pada perbedaan kinerja penyuluh yang tinggi dan rendah. Kinerja penyuluh yang tinggi diindikasikan dengan interval kunjungan lapangan yang tinggi dan transfer ilmu serta teknologi yang baik dari penyulu kepada petani. Hal ini dikarenakan penyuluh pertanian berperan sebagai penasehat di kecamatan-kecamatan yang menjadi wilayah kerjanya.

Hasil penelitian menunjukkan bahwa ada perbedaan penggunaan tenaga kerja pada usahatani padi sawah di daerah dengan kinerja penyuluh tinggi dan daerah dengan kinerja penyuluh rendah. Pada daerah kinerja penyuluh tinggi penggunaan tenaga kerja 
lebih banyak perhektar permusim tanam dibanding daerah kinerja penyuluh rendah. Tenaga kerja yang memadai dalam menjalankan usahatani tentu memudahkan petani dalam mengalokasikan sebaran perkerjaan dengan tepat waktu dan hasil yang baik. Diketahui bahwa terutama pada pemeliharaan tanaman padi sawah banyak membutuhkan tenaga kerja yang paling banyak seperti pada pemupukan, pengendalian hama dan penyakit serta penyiangan. Kalau tenaga kerja kurang tentunya fase-fase kegiatan pemeliharaan tidak berjalan dengan baik sehingga pada akhirnya pertumbuhan dan perkembangan tanaman padi juga tidak optimal. Nampaknya petani yang berada di daerah kinerja tinggi lebih memahami tentang penggunaan tenaga kerja dalam mengelola usahatani padi sawah.

Hasil penelitian menunjukkan bahwa ada perbedaan penggunaan bibit padi sawah, dimana rata-rata petani padi sawah di daerah kinerja penyuluh tinggi menggunakan bibit padi sawah sebanyak $25 \mathrm{Kg} / \mathrm{Ha} / \mathrm{MT}$ sedangkan petani padi sawah di daerah kinerja penyuluh rendah menggunakan bibit padi sawah di bawah $25 \mathrm{Kg} / \mathrm{Ha} / \mathrm{MT}$. Hal ini tentu berhubungan dengan kerapatan tanaman atau populasi tanaman padi sawah persatuan luas lahan yang ditanami. Penggunaan bibit padi persatuan sesuai anjuran tentunya akan mengahsilkan produksi yang lebih tinggi dibandingkan dengan penggunaan bibit di luar anjuran oleh penyuluh. Pemahaman petani tentang penggunaan bibit yang baik tentunya tidak terlepas pemahaman petani terhadap sistim tanam yang dianjurkan oleh penyuluh pertanian di daerahnya.

Hasil penelitian penggunaan pupuk (Urea, TSP dan KCL) bahwa ada perbedaan penggunaan ketiga jenis pupuk tersebut. Petani di daerah kinerja penyuluh tinggi menggunakan pupuk mendekati dosis anjuran dari penyuluh pertanian sedangan petani di daerah kinerja penyuluh rendah menggunakan pupuk pada usahatani padi sawah di bawah dosis anjuran. Sudah menjadi ketentuan pada penanaman padi sawah pada areal yang sama secara berulang-ulang tentunya akan menyebabkan tingkat kesuburan tanah akan menurun. Kesuburan tanah yang menurun membutuhkan perlakuan pemupukan dalam upaya menambah unsure hara ke dalam tanah sesuai kebutuhan tanaman yang ditanam. Apabila dosis pupuk yang diberikan tepat maka tanaman akan tumbuh dan berkembang secara wajar sehingga produksinya juga akan optimal. Apabila dosis pupuk yang diberikan kurang maka tanaman akan tumbuh dan kembang dengan tidak sempurna sehingga biasanya produksinya cendrung juga rendah. Nampaknya pentani di daerah kinerja penyuluh tinggi lebih memahami tentang pentingnya penggunaan pupuk yang tepat dalam upaya mencapai produksi yang optimal yang pada akhirnya akan memberikan pendapatan yang layak.

Hasil penelitian penggunaan pestisida bahwa ada perbedaan penggunaan pestisida antara petani di daerah kinerja penyuluh tinggi dan di daerah kinerja penyuluh rendah. Penggunaan pestisida di daerah kinerja penyuluh tinggi nampaknya sudah menjadi kebutuhan bagi petani sejalan dengan sekolah lapang pengendalian hama dan penyakit terpadu sehingga petani dapat memutuskan sendiri apa. kapan, bagaimana dan seberapa banyak pestisida yang digunakan untuk menjaga tumbuh kembang tanaman padi sawah. 
Begitu pula penggunaan ZPT bahwa ada perbedaan penggunaan ZPT antara petani di daerah kinerja penyuluh tinggi dan di daerah kinerja penyuluh rendah. Dari semua pemaparan pembahasan tentunya akhirnya dilihat dari perbedaan yang sangat signifikan produktivitas padi sawah daerah kinerja penyuluh tinggi dan daerah kinerja penyuluh rendah. Dapat disimpulkan dengan kinerja penyuluh pertanian yang tinggi dapat meningkatkan produktivitas padi sawah di Kabupaten Labuhanbatu Utara sehingga berdampak pada peningkatan pendapatan dan kesejahteraan petani serta ketahanan pangan daerah secara khusus dan nasional secara umum.

\section{SIMPULAN}

Daerah dengan kinerja penyuluh tinggi produktivitas padi sawah rata-rata yaitu sebesar 53,83 Kwintal/Hektar/Musim Tanam (Kw/Ha/MT) atau 5,383 Ton/Ha/MT. Sedangkan daerah dengan kinerja penyuluh rendah produktivitas padi sawah rata-rata yaitu sebesar $49,72 \mathrm{Kw} / \mathrm{Ha} / \mathrm{MT}$ atau 4,972 Ton/Ha/MT. Terdapat selisih produktivitas antara keduanya sebesar 4,11 Kw/Ha/MT atau 0,411 Ton/Ha/MT. Artinya daerah dengan kinerja penyuluh tinggi mempunyai produktivitas padi sawah lebih tinggi sebesar 4,11 Kw/Ha/MT atau 0,411 Ton/Ha/MT. Hasil uji beda rata-rata diperoleh batas atas perbedaan produktivitas padi sawah di daerah kinerja penyuluh tinggi dengan daerah kinerja penyuluh rendah $5,32482 \mathrm{Kw} / \mathrm{Ha} / \mathrm{MT}$ sedangkan batas bawah adalah 3,3774 Kw/Ha/MT. Dari hasil perhitungan tersebut diperoleh $t_{\text {cari }}=9,006$ sedangkan tinggkat signifikansi yaitu 0,000 lebih kecil dari 0,01 dengan demikian dapat disimpulkan terima Ha dan tolak Ho. Artinya ada perbedaan yang sangat signifikan antara produktivitas padi sawah daerah kinerja penyuluh tinggi dengan daerah kinerja penyuluh rendah pada tingkat kepercayaan $99 \%$ di daerah penelitian.

\section{DAFTAR PUSTAKA}

Adiwilanga, A. 1992, Ilmu Usahatani, Alumni, Bandung

Arianti. N. 2010, Analisis dan Pendapatan Usahatani Padi Pada Daerah Sentra dan Non-Sentra Di Kabupaten Lebong, Jurnal, No. 2 Vol. 2, Univ. Muhamadiyah, Bengkulu

Asda Rauf, Amelia Murtisari, Angki Rahman. 2012. Jurnal: Analisis Pendapatan Usahatani Padi Sawah Pada Sistem Tanam Legowo di Kecamatan Dungaliyo Kabupaten Gorontalo. (Rice Farming Income Analysis In Legowo Cropping Systems in Sub Dungaliyo Gorontalo regency). Fakultas Pertanian, Universitas Negeri Gorontalo.

Azwar Saihani. 2011. Jurnal: Analisis Faktor Sosial Ekonomi Terhadap Pendapatan Petani Padi Ciherang di Desa Sungai Durait Tengah Kecamatan Babirik Kabupaten Hulu Sungai Utara

Bagio Mudakir, 2011. Jurnal. Produktivitas Lahan dan Distribusi Pendapatan Berdasarkan Status Penguasaan Lahan pada Usahatani Padi (Kasus di Kabupaten Kendal Jawa Tengah), Fakultas Ekonomika dan Bisnis Universitas Diponegoro Semarang

Candra Ade, P. Sudarma, M. Udayani, P. 2013, Jurnal: Analisis Faktor-faktor Yang Mempengaruhi Produksi Padi Sawah Pada Daerah Tengah dan Hilir Aliran Sungai Ayung (Studi Kasus Subak Mambal, Kabupaten Badung dan Subak Pagutan, Kota Denpasar), Vol. 2 No. 3, Universitas Udayana, Denpasar

Daniel, M. 2002. Pengantar Ekonomi Pertanian. Bumi Aksara, Jakarta.

Diantoro, K Sunarsih, M Soejono, D. 2009, Jurnal: Faktor-faktor Yang mempengaruhi Produksi Padi Pada Kelompok Tani Patemon II Di Desa Patemon Tlogosari Kab. Bondowoso, Vol. 3 N0. 3, Univ. Jember 
Fachruddin Nasution, Yusniar Lubis \& Syaifuddin, Peranan Kinerja Penyuluh Pertanian Terhadap Peningkatan Produktivitas Padi Sawah di Kabupaten Labuhanbatu Utara.

Effendy. 2010. Jurnal: Efisiensi Faktor Produksi dan Pendapatan Padi Sawah di Desa Masani Kecamatan Poso Pesisir Kabupaten Poso

Ernoiz Antriyandarti, Susi Wuri Ani, Minar Ferichani. 2012. Jurnal: Analisis Privat dan Sosial Usahatani Padi Di Kabupaten Grobogan. SEPA : Vol. 9 No.1 September 2012 : 12 - 18 ISSN : 1829-9946. Pengajar Program Studi Agribisnis, Fakultas Pertanian, Universitas Sebelas Maret

Gujarati .2003. Ekonometrika Penelitian Dasar. Erlangga : Jakarta.

Gujarati dan Sumarno Damodar. (2003). Ekonometrika Dasar. Erlangga : Jakarta.

Hamdan, 2011, Analisis Efisiensi Faktor Produksi Pada Usahatani Padi Sawah Di Bengkulu, Jurnal Balai Pengkajian Teknologi Pertanian, Bengkulu

Hermanto, 1991, Ilmu Usahatani, Penebar Swadaya, Jakarta

Irawan, Handi. 2006. Smarter Marketing Moves. PT. Gramedia. Jakarta

Lubis, Zulkarnaen. 2012, Penggunaan Statistika Dalam Penelitian Sosial, Cetakan Kedua, Perdana Publishing, Medan

Moehar dan Daniel, 2004, Pengantar Ekonomi Pertanian, Bumi Aksara, Jakarta

Mosher, A, T. 1997. Menggerakkan Dan Membangun Pertanian. Yasaguna, Jakarta.

Mubyarto, 2002, Pengantar Ekonomi Pertanian, LP3ES, Jakarta

N.M.C. Laksmi, I.K. Suamba, I.G.A.A Amabarawati, 2010, E-Journal Agribisnis dan Agrowisata ISSN: 23016523 Vol. 1, No. 1, Juli 2012 http://ojs.unud.ac.id/index.php/JAA: Analisis Efisiensi Usahatani Padi Sawah (Studi Kasus di Subak Guama, Kecamatan Marga, Kabupaten Tabanan), Program Studi Agribisnis, Fakultas Pertanian, Universitas Udayana

Nani Sufiandi Suhanda. 2008. "Hubungan Karakteristik dengan Kinerja Penyuluh Pertanian di Provinsi Jawa Barat." Disertasi. Bogor: Institut Pertanian Bogor.

Nazir, Moh, 2005, Metode Penelitian, Cetakan Keenam, Ghalia Indonesia, Jakarta

Nurlaila, Zuraida.A, Jaelani A., 2012, Analisis Pendapatan Usahatani Padi (Oryza Sativa, L), Benih Varietas Ciherang Yang Bersertifikat dan Tidak Bersertifikat Di Kecamatan Labuan Amas Selatan Kabupaten Hulu Sungai Tengah, Jurnal, Media Sains, Vol.4 No. 1, BSN 2085-3548,Univ. Islam Kalimantan

Rahim dan Diah Retno, 2007, Ekonomika Pertanian, Penebar Swadaya, Jakarta

Rukmana, R. 2008. Usaha Tani Jagung. Kansius. Yogyakarta

Saleh, Khairul. 2008, Peranan Faktor-faktor yang Mempengaruhi Produksi Padi dan Kontribusinya Terhadap Pendapatan Wilayah Kabupaten Deli Serdang, Tesis Tidak Dipublikasikan, Pasca Sarjana, Universitas Medan Area, Medan

Sapar. 2011. "Faktor-faktor Yang Mempengaruhi Kinerja Penyuluh Pertanian Dan Dampaknya Pada Kompetensi Petani Kakao di Empat Wilayah Sulawesi Selatan.” Tesis. Bogor : Institut Pertanian Bogor.

Singgih Santoso, 2000. Buku Latihan SPSS Statistik Parametik. Jakarta: PT Elex Media Komputindo Gramedia.

Soekartawi, 1996, Analisis Usahatani, Universitas Indonesia, Jakarta

Soekartawi, 2002, Analisis Usahatani, Universitas Indonesia, Jakarta

Sudarsono, H, 1995, Pengantar Ekonomi Mikro, LP3ES, Jakarta

Sudjana, 2002, Teknik Analisa Regresi dan Korelasi, Tarsito, Bandung

Suharno, B. 2009. Kiat Sukses Berbisnis. Penebar Swadaya. Jakarta. 